\title{
Livelihood Improvement of Poor People through Microcredit in Bangladesh
}

\author{
A.H.M Mahbubur Rahman* \\ Assistant Professor and Chairman, Department of Social Work, Bangamata Sheikh Fajilatunnesa Mujib Science \\ \& Technology University (BSFMSTU), Jamalpur, Bangladesh
}

*Corresponding Author: A.H.M Mahbubur Rahman, Assistant Professor and Chairman, Department of Social Work, Bangamata Sheikh Fajilatunnesa Mujib Science \& Technology University (BSFMSTU), Jamalpur, Bangladesh

\begin{abstract}
Microcredit for women is as a proven and effective poverty alleviation intervention, with a positive impact on economic growth and a number of social development indicators. It is widely recognized that there is a direct relationship between access to credit and an increase the livelihood and status of women and men within their household and community. This article has been prepared based on a study conducted on microcredit program of BACE-Mitali Training Centre (BMTC) project which was chosen to reveal impact of microcredit on poor people livelihood. A short survey questionnaire has been used for collecting data. A 60 credit borrowers were selected as respondents randomly for interview. Research found that a significant change occurred among the beneficiaries of BMTC credit program in terms of economic condition, social and livelihood condition and empowerment.
\end{abstract}

Keywords: Microcredit, Livelihood, Women, Empowerment

\section{INTRODUCTION}

Microcredit programs' main target is women. There are strong evidences that, microcredit programs contribute to women's empowerment. It increases self-confidence and self-esteem among women. It also increases women's decision making power in the areas of family planning, children's marriage, buying and selling of properties and sending daughters to school. There are ample evidences that members of microcredit groups have been able to increase their livelihood status through using microcredit in productive sectors. Provision of credit is believed to lead to the empowerment of women. The use of microcredit is becoming increasingly common as a poverty reduction strategy within development agencies programs. Studies suggest that it has numerous positive effects on health, nutrition, education and other areas.

Microfinance programs globally considered as one of the most significant tool to fight against poverty. Wide range of researches avowed that microfinance is a successful mechanism to reach the Base of the Pyramid; it is effective tool those who are more vulnerable to many of the socioeconomic, political, cultural, and environmental shocks and risks. In the process of sustainable development "Reaching the poor and being financially sustainable" has now become the goal of microfinance program. Therefore, building the livelihood of poor people through microfinance program must be in a more sustainable manner.

\subsection{Livelihood Status of Poor People}

Increased attention is being paid to livelihood in research and policy due to wide recognition that few rural as well as urban households (especially those in middle and low income countries) rely on a single source of income. Chambers \& Conway, 1991 define livelihood as the capabilities, assets and activities required for a means of living. Livelihood is said to be sustainable when an individual is able to cope with and recover from stress and shocks, maintain or enhance capabilities and assets and provide sustainable livelihood opportunities (Carney, 1998). In disaggregating the concept of sustainable livelihood approach, FSNAU, 2009 describes livelihood as the way of life of a people which is made up of capabilities, activities and strategies needed and used by households and individuals for making a living. 
In order to meet basic needs, Frankenberger, 1996 sees livelihoods security as adequate and sustainable access to income and resources. Livelihoods are formed within social, economic and political contexts. Institutions, processes and policies, such as markets, social norms, and land ownership policies affect women's ability to access and use assets for a favourable outcome. As these contexts change they create new livelihood obstacles or opportunities.

A very important trait of livelihood is that of interdependence. Very few livelihoods exist in isolation. A given livelihood may rely on other livelihoods to access and exchange assets. Traders rely on farmers to produce goods, processors to prepare them, and consumers to buy them. Livelihoods also compete with each other for access to assets and markets. Thus positive and negative impacts on any given livelihood will, in turn, impact others.

\subsection{Microfinance and Livelihood: Literature Review}

Two key non-financial determinants of microfinance influence at household and individual level are education and health. Hashemi, (2001) contends that households of microfinance beneficiaries tend to have better nutrition, health education and health practices in comparison to households of nonmicrofinance beneficiaries.

Children are not left behind as they also gain through access to better education. Littlefield, Morduch, $\&$ Hashemi (2003) mentioned that poor people with income obtained through microfinance activities invest in their children's education i.e. children are more likely to go to school and as well as stay longer in school in comparison to children of non-microfinance beneficiaries.

Robinson (2001) and Zeller \& Meyer (2002) states that microfinance has a positive influence on the livelihoods of women. As access to microfinance leads to an enhancement in the quality of life of clients, a boost in self-confidence and has also helped in diversifying their sources of income, therefore increasing their income. Chowdhury \& Bhuiya, 2004 assesses BRACs microfinance intervention in Bangladesh and came to a conclusion that microfinance led to an improvement in basic education, lower child survival rates, and children suffered less malnutrition related diseases than children of non - members.

Therefore, a growing body of knowledge has proven that microfinance was, and still continues to positively influence at household and individual level.

In the present research it will be examined whether the participation of women in microcredit program of a Bridge of light supported project in Bangladesh has benefited them to uphold their livelihood status or not.

\section{BACKGROUND OF THE STUDY}

The fight against poverty through microcredit-programs is an important focus among the project supports of donor agencies. A remarkable amount of financial means has accumulated in the last years with individual organizations in Credit-Revolving-Funds. These credit funds are administered by the respective organizations. The major aim of the credit fund is to reduce poverty and improve livelihood condition of the targeted rural poor women in Bangladesh. Poor women receive small loan from the partner organization becoming member of samity. They invest the loan money in various sectors like agriculture, poultry, small business, grocery, etc. The credit makes them empower and help to reduce violence against them.

\subsection{Project Selected for the Study}

BACE-Mitali Training Center with Demonstration Farm (BMTC) project's credit program of BACE located at Birgonj, Dinajpur district has been taken for the present study for analysis.

\subsection{Brief about BMTC Project}

Bangladesh Association for Community Education (BACE) with the financial assistance of a foreign donor established BACE Mitali Training Centre with Demonstration Farm Project (BMTC) in Birgonj Upazila of Dinajpur district in 1999. From then it is continuing to till date.

\section{Project Components}

The Projects has 5 main components as follows: 
1) Education Program

2) Training

3) Demonstration Farm

4) Microcredit, and

5) Cultural activities

\subsection{Microcredit Program}

Microcredit has been distributed among the targeted poor and landless people (women) trough forming groups or samity for undertaking income generation activities. The microcredit program has now 106 groups, 1,883 group members, 1,822 loanee members (up to June 2019). Till 30 June, 2019 around taka 103,501,000 has been disbursed among beneficiaries. The total outstanding was taka 136, 471, 41 for the same period.

\subsection{Location of the Beneficiaries}

The project beneficiaries are from 58 villages of 10 Unions namely Shibrampur, Polashbari, Sotogram, Nijpara, Mohammadpur, Bhognagar, Satore, Mohanpur, Moricha and Birgonj Pourashava of Birgonj sub-district under Dinajpur district, Bangladesh. In terms of economic and educational condition, Birgonj Upazila is relatively disadvantaged in comparison to other areas. The majorities of the families live below the poverty level and are not able to meet the basic necessities of life. Around $83 \%$ of the inhabitants earn their livelihood by agriculture. Most of them are poor and landless. A majority of people have no land or employment opportunity.

\section{Methodology OF THE STUdY}

\subsection{Research Approach}

The research has been carried out using both qualitative and quantitative research methods. A survey has been conducted among the selected credit beneficiaries of the project. A well structured short questionnaire was used for this purpose. The contents of the questionnaire were determined according to the objective of the research. Credit beneficiaries' present situation and prior situation (before joining the credit program) regarding economic condition and empowerment were assessed setting proper questions. However, to get an in-depth picture of livelihood development some case studies were also conducted among the credit beneficiaries.

\subsection{Objective of the Study}

The major objective of this accompanying study was to reveal whether microcredit facilitated to improve the livelihood status of a credit program's beneficiaries (women) or not. The specific objective of the present study are:

1. To see the changes in economic condition

2. To reveal the social and livelihood condition, and

3. To assess their empowerment

\subsection{Sample Design}

Till June 2019 there were 1,883 group members. Out of them around 1,200 beneficiaries are within credit program for more than 12 years. Simple Random Sampling (SRS) method was adapted to select the respondents for the present research. Only those who are in the credit program for more than 12 years were selected as respondents for the study.

\subsection{Sample Size}

A $5 \%$ of the total credit beneficiaries among 1,200 beneficiaries within 12 years involvement in the credit program have been randomly selected as respondents. So, the number of respondents was 60 . It is noted here that 60 beneficiaries have been selected from 10 villages of 10 Unions under BMTC project. Moreover, 3 case studies were also conducted among the beneficiaries from 3 villages under BMTC project area.

\subsection{Selection of Respondents}

Purposive sampling method was applied to select the respondents for interview. 


\subsection{Data Collection Tools}

\section{- Survey Questionnaire}

A well structured short questionnaire has been used to collect necessary information from the credit beneficiaries. The questionnaire was designed in Bengali using familiar words and unequivocal and straightforward for easy understanding of the respondents.

\subsection{Field Data Collection}

Field data were collected from the selected respondents of BMTC microcredit beneficiaries. Four data collectors (mainly experienced senior credit officer of BMTC project) were deployed and trained. They helped the researcher to select appropriate cases and to collect information or data from the selected respondents. Moreover, 1 data editor, 1 data coder, 1 data analyst and 1 data entry operator were also recruited in this regard. Beside primary data, secondary materials (such as books, journals, documents, survey and evaluation reports and research studies) were also reviewed and used in this study.

\subsection{Data Analysis}

After having data from the field the first step is their processing as editing, coding, cleaning and entry. To analyze the data SPSS software was used in this regard. The data was presented in various tabular, graphical and statistical processes in this report.

\section{FIndings OF The STUd}

\subsection{Background Profile of the Respondents}

This section portrays the demographic and social conditions, such as the age structure, education, occupation, religion of the respondents. Moreover, changes in the economic, livelihood condition and empowerment status have also been assessed in this section.

\section{Profile of Samity Member}

\section{Age Structure}

Analysis of age structure shows that majority of the female respondents (31.6\%) belong to the middle age group (36-40 years). More than one-fourth (30\%) of them have been found comparatively young (age ranging from 31 to 35 ). About $17 \%$ of the respondents belong to young age group (26-31 years) and only $6.7 \%$ of them have found over 45 years and over age group. The mean age of the respondents is 36.38 years and the maximum age is 49 and minimum age is 28 years (Table 3.1).

\section{Educational Profile}

Educational status is considered as one of the prime components of human capital. Analysis shows that out of the total respondents (60) about one-third of them (31.6\%) completed primary level education (Class five). Only around $6.7 \%$ of them have secondary level education (SSC and equivalent) and a majority of them (61.7\%) can sign their name only (Figure 3.2).

\section{Occupational Profile}

Distribution of occupational pattern shows that about two-thirds (65\%) of the respondents are housewife. The second largest portion of the respondents $(32.7 \%)$ have found as laborer. On the other hand, only $3.3 \%$ of them reported farming as their prime occupation (Figure 3.3).

\section{Religion}

The religion distribution of the respondents shows that most of them are Muslim (46.6\%). About onethird (31.7\%) of them are Hindu and over one-fifth (21.7\%) belong to indigenous like Santal religion (Figure 3.4).

\section{Duration of Samity Membership}

The duration of membership of samity shows that over one-fifth of the members (21.7\%) are involved in samity activities till around 11 years. Over one-fourth (26.6\%) of them have membership with the Samity for around 9 years and $25 \%$ of them for 10 years. Only $1.7 \%$ of them have found 5 years involvement with Samity activities. The mean year of Samity membership is 9.27 years (Figure 3.5). 


\section{Frequencies of Loan Taken by Samity Member}

It has been found that around $21.7 \%$ of the members took highest 11 times loan from samity. Around 10 times has taken by $25 \%$ members and 9 times by $26.6 \%$ members. Around 5 times loan has taken only by $1.7 \%$ members (Table 3.1 ).

Table3.1. Percentage distribution of the respondents according to the number of taking loan from Samity.

\begin{tabular}{|c|c|c|}
\hline Frequency/ number of loan & Frequency & \% (Total) \\
\hline 5 & 1 & 1.7 \\
\hline 7 & 6 & 10.0 \\
\hline 8 & 9 & 15.0 \\
\hline 9 & 16 & 26.6 \\
\hline 10 & 15 & 25.0 \\
\hline 11 & 13 & 21.7 \\
\hline Total & $\mathbf{6 0}$ & $\mathbf{1 0 0 . 0}$ \\
\hline
\end{tabular}

\section{Total Amount of Loan money Taken by Samity Member}

It has been found that majority of the respondents $(38.3 \%)$ has taken total amount of money within the range of 81,000 to 100,000 . Only $1.7 \%$ of them have taken loan from the Samity taka 140,000 and more .And only $5 \%$ of them have taken loan within the range of taka 1,000 to 20,000. Over one-fifth $(21.7 \%)$ of them has taken total amount of loan as taka 61,000 to 80,000 . The mean amount of loan money taken by loanee members is taka 78,003.33 (Table 3.2).

Table3.2. Percentage distribution of the respondents according to their total amount of loan taken

\begin{tabular}{|l|l|l|}
\hline Total amount of loan in taka & Frequency & \% (Total) \\
\hline $1,000-20,000$ & 3 & 5.0 \\
\hline $21,000-40,000$ & 4 & 6.7 \\
\hline $41,000-60,000$ & 8 & 13.3 \\
\hline $61,000-80,000$ & 13 & 21.7 \\
\hline $81,000-1,00,000$ & 23 & 38.3 \\
\hline $1,01,000-1,20,000$ & 6 & 10.0 \\
\hline $1,21,000-1,40,000$ & 2 & 3.3 \\
\hline $1,40,000+$ & 1 & 1.7 \\
\hline Total & $\mathbf{6 0}$ & $\mathbf{1 0 0 . 0}$ \\
\hline
\end{tabular}

Amount of Last Loan Money

It has also been found that only $3.3 \%$ of the respondents have taken taka 27,000 as last loan money. The highest portion of the respondents is $11.7 \%$ who has taken 18,000 as the last loan money and also the same portion of them have mentioned taka 10,000 as their last loan money. Taka 11,000, 12,000 and 14,000 have mentioned as last loan money by same portion of the respondents (8.3\%) (Table 3.3).

Table3.3. Percentage distribution of the respondents according to their response on last loan money

\begin{tabular}{|l|l|l|}
\hline Amount of last loan money in taka & Frequency & \% (Total) \\
\hline 7000 & 3 & 5.0 \\
\hline 9000 & 3 & 5.0 \\
\hline 10000 & 7 & 11.7 \\
\hline 11000 & 5 & 8.3 \\
\hline 12000 & 5 & 8.3 \\
\hline 13000 & 4 & 6.7 \\
\hline 14000 & 5 & 8.3 \\
\hline 15000 & 3 & 5.0 \\
\hline 16000 & 2 & 3.3 \\
\hline 17000 & 4 & 6.7 \\
\hline 18000 & 7 & 11.7 \\
\hline 19000 & 2 & 3.3 \\
\hline 20000 & 4 & 6.7 \\
\hline 22000 & 2 & 3.3 \\
\hline 25000 & 1 & 1.7 \\
\hline 26000 & 1 & 1.7 \\
\hline
\end{tabular}




\begin{tabular}{|l|l|l|}
\hline 27000 & 2 & 3.3 \\
\hline Total & $\mathbf{6 0}$ & $\mathbf{1 0 0 . 0}$ \\
\hline
\end{tabular}

\section{Income Generating Activities (IGA) Sectors Where Loan Money Utilized}

It has been found that more than one-third of the member respondents utilized their loan money in livestock (cow and goat raring) sector. On the other hand around 31.6\% of them utilized it in cultivation. The others sectors are rickshaw/van purchase and land purchase (Table 3.4).

Table3.4. Percentage distribution of the respondents according to their response on purpose (IGA) of spending money

\begin{tabular}{|l|l|l|}
\hline Purpose of spending money & Frequency & \% (Total) \\
\hline Livestock (Cow and goat raring) & 21 & 35.0 \\
\hline Cultivation & 19 & 31.6 \\
\hline Small business & 18 & 30.0 \\
\hline Rickshaw / van purchase & 1 & 1.7 \\
\hline Land purchase & 1 & 1.7 \\
\hline Total & $\mathbf{6 0}$ & $\mathbf{1 0 0 . 0}$ \\
\hline
\end{tabular}

\section{Person Encouraged Becoming Samity Member}

Majority portion of the women respondents (75\%) reported that 'Credit Supervisor' of BMTC project encouraged them to become Samity member. The person or factors are 'Group Leader' (5\%), 'Social Worker' (10\%) and 'Self Motivation' (10\%) (Figure 3.6).

\subsection{Changes in Economic Condition of the Member Respondents}

The changes in the economic condition of the samity members were also revealed in the present research. Some indicators were set in this regard to know their prior situation and present situation. Those are depicted below.

\section{Changes in Income}

It has been found that around two-fifths of the Samity members reported that their monthly income has increased significantly. On the other hand more than half of them mentioned that their income has increased moderately (Table 3.5).

\section{Changes in Wage}

Majority of member respondents $(70 \%)$ mentioned that after having membership with BMTC microcredit program their wage has increased moderately. On the other hand around $15 \%$ of the respondents reported that their wage increased notable and the same portion mentioned that it increased a little bit (Figure 3.8).

\section{Changes in Employment (Work Pattern)}

A large portion of the member respondents $(70 \%)$ mentioned that changes happened moderately in their employment pattern due to becoming samity member and taking loan from the samity. Each of $15 \%$ of them reported that their employment pattern changed significantly and a little bit. Only $17 \%$ of them told that it has changed but not significantly (Figure 3.9).

\section{Changes in Land and House Ownership}

More than half of the respondents (58.8\%) have stated that after involvement with BMTC credit program their land and house ownership status has increased moderately. Around one-fifth (20\%) of them mentioned that it increased a little bit. Only $10 \%$ of them mentioned that it increased notable (Figure 3.10).

\section{Changes in Essential Household Assets Ownership}

Around $45 \%$ of member respondents mentioned that their ownership in essential household assets has increased moderately while around $30 \%$ of them mentioned it as significantly increased (Figure 3.11).

\section{Changes in the Ownership of Cow, Goat,}

\section{Duck and Chicken}

Around half of the member respondents (50\%) mentioned that after becoming member in the Samity their ownership of cows, goat, duck and chicken has increased moderately. On the other hand around $43.3 \%$ of them reported that their ownership on the same has increased significantly (Figure 3.12). 
Based on the findings it can be said that there happened a significant changes in income, wage, employment and ownership on land, household assets, etc of the member of BACE BMTC project.

\subsection{Changes in Social and Livelihood Condition}

The changes in the social and livelihood condition of the samity members were also revealed in the present research. Some indicators were set in this regard to know their prior situation and present situation. Those are presented below.

\section{Affordability of taking 3 times nutritious meal in a day}

A large majority of the respondents $(85 \%)$ mentioned that at present they are capable enough to take 3 times nutritious food in a day and only $15 \%$ of them reported that they can afford it irregularly / sometimes. On the other hand a good portion of them (78.3\%) mentioned that before becoming Samity member they could not manage 3 times nutritious food always in a day and over one-fifth of them $(21.7 \%)$ can never afford it (Figure 3.7). Thus, there is a significant change happened among the Samity member having 3 times meal in a day. A major portion who earlier could afford irregularly or sometimes to manage 3 times meal in a day earlier they now can manage it regularly.

\section{Ability of Sending Children into School}

Almost all the member respondents (96.7\%) mentioned that at present they have the ability to send their children in to school. On the other hand before becoming member of the samity more than half (56.7\%) of them had the ability to send their children irregularly and $43.3 \%$ of them could not send their children in to school at all (Figure 3.14).

\section{Affordability of Taking Medical Treatment during Illness}

A large majority of the member respondents $(81.7 \%)$ reported that they are now capable enough to take medical treatment for their family members during illness. On the other hand more than half of them $(55 \%)$ mentioned that before becoming Samity member they could not afford treatment regularly during illness of their family members and $41.7 \%$ of them could not take the treatment at all (Figure 3.15).

\section{Affordability of Buying Necessary Clothes for All Members}

Around $60 \%$ of the member respondents stated that at present they have the ability to buy all necessary clothes for all members of the family. On the other hand, around same portion of them could manage all necessary clothes for their family members before becoming samity members (Figure 3.16).

Thus, it can be inferred that BMTC credit program has brought a significant change of the members of affordability of taking 3 times meal, sending children into school, taking medical treatment and buying necessary clothes for family members.

\subsection{Empowerment}

Empowerment of women is a process through which women in general and poor women in particular get the opportunity to join the workforce, contribute to family income, and have dignity, recognition and place in family as well as in society. Education of girls and women is an indispensible tool to empower women.

For the present study to assess the empowerment of women member respondents at household level some indicators were set. Those are analyzed below.

\section{Use of Loan Money Independently}

A widely spread criticism of microcredit is that loanee women cannot control over their loans and management power of the activities for which the loans are used. In cases, where wives had taken small loans, from any source, husbands reported that they use their wives' loan money to spend on their own income generating projects. In the present research among women who had taken loans for income- generating activities, $68.3 \%$ reported having total autonomous control over the money. $31.7 \%$ reported that they share control over the loan money with their husbands that mean sometimes they can use the loan money independently (Figurer 3.17). So, the loanee members of BMTC project are more empowered to use their loan money. 


\section{Working outside the Home}

Although at present women are working in different sectors outside the home but majority of our society people believe the traditional view that home is the only work place for women in our society. Only male is fit for work outside the home. If any women goes to work outside the home majority of the society people cannot accept it as a very simple matter. So, women who go to work outside the home have to face many awful situations. In the present study this fact has also been explored. According to the data majority of the women respondents $(68.3 \%)$ admitted that before becoming Samity member they could not work outside the home. But at present $30 \%$ of them can work outside always and over two-third (66.7\%) of them can work sometimes (Figure 3.18). The respondents who stated that they can or could do any work outside home also mentioned the reasons of it. The reasons that they mentioned are: husband does not like it; others family members do not like it; they do not consider themselves able/fit; surroundings condition is not favorable, etc (Please see table 22 in annex).

\section{Participation in Samity Meeting}

Now a day many women can participate in the Samity (microcredit group) and social activities. But 15 to 20 years ago it was impossible to many of Bangladeshi women to participate in the Samity meeting. In the present research about 81.7 percent member respondents stated that they could not participate in any Samity/CBO/ social activities before becoming Samity member. On the other hand, now a day, almost all of them (93.3\%) can participate in the Samity meeting and other social activities (Figure 3.19). The reasons for not participating in Samity activities are: surroundings condition is not favorable; husband does not like it; others family members do not like it, etc (Please see table 23 in annex).

\section{Taking Decision on Any issue of the Family}

More than two-third (68.3\%) of women members respondents reported that at present they can take decision on any issue of the family while about same portion of them (66.7\%) could not do so before becoming Samity member. About one-third of them (31.7\%) told that at present some of them can take decision on any issue of the family (Figure 3.20). The reasons of inability to take decision are: husband does not like it; others family members do not like it, etc (Please see table 24 in annex).

\section{Visiting Relative's House}

Due to patriarchal social system women in our society cannot visit relatives and friends whenever they wish; they have to seek permission from their male counterpart to visit relatives. It has been found that more than half respondents $(53.3 \%)$ reported that now they can visit relatives house whenever they wish but before becoming Samity member they could not visit relatives house without the permission of their husband and their portion is around 45\%. (Figure 3.21). Respondents who could not visit relative's house mentioned some reasons. The reasons are: husband does not like it; other family members do not like it, etc (Please see Table 25 in annex).

\section{Spending Money Independently}

Generally women in our society cannot spend money independently rather they need permission from their husband (or other male members in the absence of husband). But in the present study, around $46.7 \%$ of member respondents reported that they can spend money without the permission of their husband but more than half $(53.3 \%)$ of them stated that they can do this sometimes. On the other hand over three-fourth (76.7\%) of them admitted that before becoming Samity member they could not spend any money independently (Figure 3.22). In most cases husbands do not permit their wife to spend money independtly. The other prime reasons are: other family members do not like it; surroundings condition is not favorable, etc (Please see table 26 in annex).

\section{Participation in Village Arbitration System}

In our society it is belief or tradition that doing 'Shalish' (a non formal court where village leaders mitigate disputes) or judgment is the duty of men. However, in the present research a major portion (96.7\%) of member respondents opined that they could not participate in the village arbitration before becoming samity member but at present around $90 \%$ of them can participate there sometimes (Figure 3.23). Respondents mentioned the reasons for not participating in the village arbitration system. Those are: husband does not like it; others family members do not like it, etc (Please see table 27 in annex). 


\section{Husband Count them in any Issue}

A 68.3 percent of member respondents stated that at present their husband seek suggestions in the decision making process. On the other hand, a large portion of them stated that before becoming Samity member their husband did not count them in any decision making process (Figure 3.24). Respondents who stated that their husbands do not count them also mentioned the following reasons. Those are: husband does not like it; others family members do not like it; they do not consider themselves able/fit; others family members do not like it, etc (Please see table 28 in annex).

\section{Use of Sanitary Latrine}

Use of sanitary latrine (hygienic latrine) is also an indicator of empowerment of microcredit group members. The data of the following table shows that before joining BMTC credit group no one of the selected respondents could use sanitary latrine. But at present almost all of them (98.3\%) have installed sanitary latrine in their household and now they can use it. It is an indication of livelihood, as well as results of improvement of their awareness level which happened due to receiving training from the BMTC center (Table 3.5).

Table3.5. Percentage distribution of the respondents according to their response on having sanitary latrine in the household

\begin{tabular}{|l|l|l|l|l|}
\hline \multirow{2}{*}{ Having sanitary latrine } & Present & Before & \% (Total) \\
\cline { 2 - 5 } & Frequency & \% (Total) & Frequency & \% \\
\hline Yes & 59 & 98.3 & - & - \\
\hline No & 1 & 1.7 & 60 & 100.0 \\
\hline Total & 60 & 100.0 & 60 & 100.0 \\
\hline
\end{tabular}

\section{Increased Social Acceptance}

Microcredit membership enhances the social status and acceptance of poor people. In the present research almost all of the survey respondents (98.3\%) admitted that their social acceptance has been increased after joining BMTC credit group (Table 3.6).

Table3.6. Percentage distribution of the respondents according to their response on increasing social acceptance

\begin{tabular}{|l|l|l|l|l|}
\hline \multirow{2}{*}{ Increased social acceptance } & Present & Before & \% (Total) \\
\cline { 2 - 5 } & Frequency & \% (Total) & Frequency & - \\
\hline Yes & 59 & 98.3 & - & - \\
\hline No & 1 & 1.7 & - & 100.0 \\
\hline Total & 60 & 100.0 & 60 & . \\
\hline
\end{tabular}

All of the respondents mentioned that their social acceptance has increased after becoming BMTC credit group member and taking loan from it.

Based on the above mentioned findings, it is now evident that BMTC microcredit program has helped its beneficiaries (particularly poor women) to improve their livelihood, to become self-empowered and paved their way for their inclusion to the greater society.

\section{CONCLUSiON}

It has proved through various studies that microcredit facilitated improving livelihood condition of numerous poor people in different parts of the world. Microcredit is not only poverty - reducing tool but it has many positive effects on women empowerment, health and improving gender relations. In the present research it has also proved that microcredit has helped a lot to poor women of a foreign donor supported credit programe in the Dinajpur region of Bangladesh. The present research would be helpful to understand the significant relationship between microcredit program and livelihood improvement of poor people in Bangladesh. It will also be helpful for policy makers and organizations to adopt additional proper actions for program intervention to improve the sustainable livelihood condition of poor women in Bangladesh.

\section{REFERENCES}

[1] Ahmed, F., Siwar, C and Idris, N.A.H. (2011). The sustainable livelihood approach: Reduce poverty and vulnerability, Journal of Applied Science and Research, 7: 810-813.

[2] Amin, S., Rai, A. S., and Topa, G. (2003). Does microcredit reach the poor and vulnerable? Evidence from Northern Bangladesh, Journal of Development Economics, 70(1). 
[3] Arora, B. and Singhal, A. (2013). A comprehensive Literature on Impacts of Microfinance. Online International Interdisciplinary Research Journal, ISSN 2249-9598, 3(5): 346-358.

[4] Ashley, C, and Carney, D. (1999). Sustainable Livelihoods: Lessons from the early experience, London: Department for International Development (DFID).

[5] Augburg, B., Haas, D. R., Harmgart, H. and Meghir, C. (2012). Microfinance, Poverty and Education, National Bureau of Economic Research.

[6] Ayuub, S. (20130. Impact of Microfinance on Poverty Alleviation: A Case Study of NRSP in Bahawalpur of Pakistan International Journal of Academic Research in Accounting, Finance and Management Sciences, 3(1).

[7] Basher, M. A. (2010). Promotional role of microcredit: Evidence from the Grameen Bank of Bangladesh, Journal of International Development, 22: 521-529. (DOI: 10.1002/jid.1583).

[8] Bateman, M. (2011). Microfinance as a development and poverty reduction policy: is it

[9] Carney, D. Sustainable Livelihoods Approaches: Progress and Possibilities for Change, Department for International Development DFID, ISBN: 1861924917.

[10] Chambers, R and Conway, G. (1991). Sustainable Rural Livelihoods: Practical Concepts for the 21st Century.

[11]DFID. (1999). Sustainable livelihoods guidance sheets. London: Department for international Development. everything it ${ }^{\text {ee }}$ c cracked up to be?, Overseas Development Institute, pp: 1-4

[12] Hossain, A., Hossain, M and Rezaul, K. (2010). Impact of microfinance operations on the livelihood of the clients: A review of the existing literature. Digital Bus., 21: 166-174. (DOI: 10.1007/978-3-642- 115325_19).

[13] Khandker, S. (2001). Does Micro-finance really benefit the Poor? Evidence from Bangladesh, Paper delivered at Asia and Pacific Forum on Poverty: Reforming Policies and Institutions for Poverty Reduction held by the Asian Development Bank. Manila, pp: 1-19

[14] Rahman, Muhammad Matiur (2012),'Domestic Violence on Women in Bangladesh: A Case Study of Jhenaidah' Unpublished PhD thesis, Institute of Bangladesh Studies, University of Rajshahi, Rajshahi, Bangladesh.

[15] Susy Cheston, and Lisa Kuhn (2010), 'Empowering Women through Microfinance' Research sponsored by the Women's Opportunity Fund and its funding partners: Elizabeth Foster and Michael Walsh, Gems of Hope USA, and the Morrow Charitable Trust.

\section{Table}

1. Percentage Distribution of the Respondents According to Their Age Structure

\begin{tabular}{|l|l|l|}
\hline Age range & Frequency & \% (Total) \\
\hline $26-30$ & 10 & 16.7 \\
\hline $31-35$ & 18 & 30.0 \\
\hline $36-40$ & 19 & 31.6 \\
\hline $41-45$ & 9 & 15.0 \\
\hline $46-50$ & 4 & 6.7 \\
\hline $51+$ & - & - \\
\hline Total & $\mathbf{6 0}$ & $\mathbf{1 0 0 . 0}$ \\
\hline
\end{tabular}

Minimum age: 28

Maximum age $=49$

Mean age $=36.38$

2. Percentage Distribution of the Respondents According to Their Education

\begin{tabular}{|l|l|l|}
\hline Education category & Frequency & \% (Total) \\
\hline Can sign only & 37 & 61.7 \\
\hline Primary (Class 1-5) & 19 & 31.6 \\
\hline Secondary (Class 6-10) & 4 & 6.7 \\
\hline Total & $\mathbf{6 0}$ & $\mathbf{1 0 0 . 0}$ \\
\hline
\end{tabular}

3. Percentage Distribution of the Respondents According to Their Main Occupation

\begin{tabular}{|l|l|l|}
\hline Occupation & Frequency & \% (Total) \\
\hline Housewife & 39 & 65.0 \\
\hline Labor & 19 & 31.7 \\
\hline
\end{tabular}


Livelihood Improvement of Poor People through Microcredit in Bangladesh

\begin{tabular}{|l|l|l|}
\hline \multicolumn{2}{|l|}{} \\
\hline Farmer & 2 & 3.3 \\
\hline Total & $\mathbf{6 0}$ & $\mathbf{1 0 0 . 0}$ \\
\hline
\end{tabular}

4. Percentage Distribution of the Respondents According to Their Religion

\begin{tabular}{|l|l|l|}
\hline Religion & Frequency & \% (Total) \\
\hline Islam & 28 & 46.6 \\
\hline Hindu & 19 & 31.7 \\
\hline Santhal (Indigenous) & 13 & 21.7 \\
\hline Total & $\mathbf{6 0}$ & $\mathbf{1 0 0 . 0}$ \\
\hline
\end{tabular}

5. Percentage Distribution of the Respondents According to Their Response on Year of Involvement in Samity Activities.

\begin{tabular}{|c|c|c|}
\hline Year of involvement in samity & Frequency & \% (Total) \\
\hline 5 & 1 & 1.7 \\
\hline 7 & 6 & 10.0 \\
\hline 8 & 9 & 15.0 \\
\hline 9 & 16 & 26.6 \\
\hline 10 & 15 & 25.0 \\
\hline 11 & 13 & 21.7 \\
\hline Total & $\mathbf{6 0}$ & $\mathbf{1 0 0 . 0}$ \\
\hline
\end{tabular}

Mean year: 9.27

6. Percentage Distribution of the Respondents According to The Number of Taking Loan From Samity

\begin{tabular}{|c|c|c|}
\hline Frequency of loan & Frequency & \% (Total) \\
\hline 5 & 1 & 1.7 \\
\hline 7 & 6 & 10.0 \\
\hline 8 & 9 & 15.0 \\
\hline 9 & 16 & 26.6 \\
\hline 10 & 15 & 25.0 \\
\hline Total & 13 & 21.7 \\
\hline
\end{tabular}

Mean loan: 9.82

7. Percentage Distribution of the Respondents According to Their Taking of Total Amount of Loan

\begin{tabular}{|l|l|l|}
\hline Total amount of loan in taka & Frequency & \% (Total) \\
\hline $1000-20000$ & 3 & 5.0 \\
\hline $21000-40000$ & 4 & 6.7 \\
\hline $41000-60000$ & 8 & 13.3 \\
\hline $61000-80000$ & 13 & 21.7 \\
\hline $81000-100000$ & 23 & 38.3 \\
\hline $101000-120000$ & 6 & 10.0 \\
\hline $121000-140000$ & 2 & 3.3 \\
\hline $140000+$ & 1 & 1.7 \\
\hline Total & $\mathbf{6 0}$ & $\mathbf{1 0 0 . 0}$ \\
\hline
\end{tabular}

Mean taka: 78003.33

8. Percentage Distribution of the Respondents According to Their Response on Last Loan Money

\begin{tabular}{|l|l|l|}
\hline Amount of last loan money in taka & Frequency & \% (Total) \\
\hline 7000 & 3 & 5.0 \\
\hline 9000 & 3 & 5.0 \\
\hline 10000 & 7 & 11.7 \\
\hline 11000 & 5 & 8.3 \\
\hline 12000 & 5 & 8.3 \\
\hline 13000 & 4 & 6.7 \\
\hline 14000 & 5 & 8.3 \\
\hline 15000 & 3 & 5.0 \\
\hline 16000 & 2 & 3.3 \\
\hline
\end{tabular}


Livelihood Improvement of Poor People through Microcredit in Bangladesh

\begin{tabular}{|l|l|l|}
\hline \multicolumn{2}{|l|}{} & 6.7 \\
\hline 17000 & 4 & 11.7 \\
\hline 190000 & 7 & 3.3 \\
\hline 20000 & 2 & 6.7 \\
\hline 22000 & 4 & 3.3 \\
\hline 25000 & 2 & 1.7 \\
\hline 26000 & 1 & 1.7 \\
\hline 27000 & 1 & 3.3 \\
\hline Total & 2 & $\mathbf{1 0 0 . 0}$ \\
\hline
\end{tabular}

Mean of last loan 14883.33

9. Percentage Distribution of the Respondents According to Their Response on Purpose (IGA) of Spending Money

\begin{tabular}{|l|l|l|}
\hline Purpose of spending money & Frequency & \% (Total) \\
\hline Livestock (Cow and goat raring) & 21 & 35.0 \\
\hline Cultivation & 19 & 31.6 \\
\hline Small business & 18 & 30.0 \\
\hline Rickshaw / van purchase & 1 & 1.7 \\
\hline Land purchase & 1 & 1.7 \\
\hline Total & $\mathbf{6 0}$ & $\mathbf{1 0 0 . 0}$ \\
\hline
\end{tabular}

10. Percentage Distribution of the Respondents According to Their Response on Who Encourage to Become Samity Member

\begin{tabular}{|l|l|l|}
\hline Person encouraged to become members & Frequency & \% (Total) \\
\hline Credit supervisor & 45 & 75.0 \\
\hline Group leader & 3 & 5.0 \\
\hline Social Worker & 6 & 10.0 \\
\hline Self-motivation & 6 & 10.0 \\
\hline Total & $\mathbf{6 0}$ & $\mathbf{1 0 0 . 0}$ \\
\hline
\end{tabular}

11. Percentage Distribution of the Respondents According to Their Response on Changes in Income after Becoming Samity Member.

\begin{tabular}{|l|l|l|}
\hline Indicators: Income & Frequency & \% (Total) \\
\hline Notable increased & 24 & 40.0 \\
\hline Moderately increased & 36 & 60.0 \\
\hline Total & $\mathbf{6 0}$ & $\mathbf{1 0 0 . 0}$ \\
\hline
\end{tabular}

12. Percentage Distribution of the Respondents According to Their Response on Changes in Wage after Becoming Samity Member.

\begin{tabular}{|l|l|l|}
\hline Indicators: Wage & Frequency & \% (Total) \\
\hline Notable increased & 9 & 15.0 \\
\hline Moderately increased & 42 & 70.0 \\
\hline A little bit increased & 9 & 15.0 \\
\hline Total & $\mathbf{6 0}$ & $\mathbf{1 0 0 . 0}$ \\
\hline
\end{tabular}

13. Percentage Distribution of the Respondents According to Their Response on Changes in Employment after Becoming Samity Member

\begin{tabular}{|l|l|l|}
\hline Indicators: Employment & Frequency & \% (Total) \\
\hline Notable increased & 12 & 20.0 \\
\hline Moderately increased & 31 & 51.6 \\
\hline A little bit increased & 16 & 26.7 \\
\hline Increased but not significantly & 1 & 1.7 \\
\hline Total & $\mathbf{6 0}$ & $\mathbf{1 0 0 . 0}$ \\
\hline
\end{tabular}

14. Percentage Distribution of the Respondents According to Their Response on Changes in Land And House Ownership after Becoming Samity Member

\begin{tabular}{|l|l|l|}
\hline Indicators: Land and house ownership & Frequency & \% (Total) \\
\hline Notable increased & 6 & 10.0 \\
\hline Moderately increased & 35 & 58.3 \\
\hline
\end{tabular}


Livelihood Improvement of Poor People through Microcredit in Bangladesh

\begin{tabular}{|l|l|l|}
\hline A little bit increased & 12 & 20.0 \\
\hline Increased but not significantly & 7 & 11.7 \\
\hline Total & $\mathbf{6 0}$ & $\mathbf{1 0 0 . 0}$ \\
\hline
\end{tabular}

15. Percentage Distribution of the Respondents According to Their Response on Changes of Essential Household Assets.

\begin{tabular}{|l|l|l|}
\hline Indicators: Essential household assets & Frequency & \% (Total) \\
\hline Notable increased & 18 & 30.0 \\
\hline Moderately increased & 27 & 45.0 \\
\hline A little bit increased & 14 & 23.3 \\
\hline Increased but not significantly & 1 & 1.7 \\
\hline Total & $\mathbf{6 0}$ & $\mathbf{1 0 0 . 0}$ \\
\hline
\end{tabular}

16. Percentage Distribution of the Respondents According to Their Response on Having Ownership of Cow, Goat, Duck, Chicken.

\begin{tabular}{|l|l|l|}
\hline Indicators: Ownership of cow, goat, duck, chicken & Frequency & \% (Total) \\
\hline Notable increased & 26 & 43.3 \\
\hline Moderately increased & 30 & 50.0 \\
\hline A little bit increased & 4 & 6.7 \\
\hline Total & $\mathbf{6 0}$ & $\mathbf{1 0 0 . 0}$ \\
\hline
\end{tabular}

17. Percentage Distribution of the Respondents According to Their Response on the Changes on Affordability of Taking Nutritious Food 3 Times in a Day.

\begin{tabular}{|l|l|l|l|l|}
\hline \multirow{2}{*}{$\begin{array}{l}\text { Affordability of taking 3 times nutritious } \\
\text { food }\end{array}$} & Present & Before & \\
\cline { 2 - 5 } & Frequency & \% (Total) & Frequency & \% (Total) \\
\hline Can afford regularly/ always & 51 & 85.0 & - & - \\
\hline Can afford irregularly / sometimes & 9 & 15.0 & 47 & 78.3 \\
\hline Never can afford & - & - & 13 & 21.7 \\
\hline Total & $\mathbf{6 0}$ & $\mathbf{1 0 0 . 0}$ & $\mathbf{6 0}$ & $\mathbf{1 0 0 . 0}$ \\
\hline
\end{tabular}

18. Percentage Distribution of the Respondents According to Their Response on Ability to Send Children into School.

\begin{tabular}{|l|l|l|l|l|}
\hline \multirow{2}{*}{ Ability to send children into school } & Present & Before & \multicolumn{2}{|l|}{} \\
\cline { 2 - 5 } & Frequency & \% (Total) & Frequency & \% (Total) \\
\hline Can afford regularly/ always & 58 & 96.7 & - & - \\
\hline Can afford irregularly / sometimes & 2 & 3.3 & 34 & 56.7 \\
\hline Never can afford & - & - & 26 & 43.3 \\
\hline Total & $\mathbf{6 0}$ & $\mathbf{1 0 0 . 0}$ & $\mathbf{6 0}$ & $\mathbf{1 0 0 . 0}$ \\
\hline
\end{tabular}

19. Percentage Distribution of the Respondents According to Their Response on Their Ability to Take Medical Treatment during Illness.

\begin{tabular}{|l|l|l|l|l|}
\hline $\begin{array}{l}\text { Affordability of taking medical } \\
\text { treatment during illness }\end{array}$ & Present & Before & \\
\cline { 2 - 5 } & Frequency & \% (Total) & Frequency & \% (Total) \\
\hline Can afford regularly/ always & 49 & 81.7 & 2 & 3.3 \\
\hline Can afford irregularly / sometimes & 11 & 18.3 & 33 & 55.0 \\
\hline Never can afford & - & - & 25 & 41.7 \\
\hline Total & $\mathbf{6 0}$ & $\mathbf{1 0 0 . 0}$ & $\mathbf{6 0}$ & $\mathbf{1 0 0 . 0}$ \\
\hline
\end{tabular}

20. Percentage Distribution of the Respondents According to Their Response on Their Ability of Buying Necessary Clothes for All Members.

\begin{tabular}{|l|l|l|l|l|}
\hline $\begin{array}{l}\text { Affordability of buying necessary } \\
\text { clothes for all members }\end{array}$ & Present & Before & \multicolumn{1}{|l|}{} \\
\cline { 2 - 5 } & Frequency & \% (Total) & Frequency & \% (Total) \\
\hline Can afford regularly/ always & 36 & 60.0 & - & - \\
\hline Can afford irregularly / sometimes & 24 & 40.0 & 24 & 40.0 \\
\hline Never can afford & - & - & 36 & 60.0 \\
\hline Total & $\mathbf{6 0}$ & $\mathbf{1 0 0 . 0}$ & $\mathbf{6 0}$ & $\mathbf{1 0 0 . 0}$ \\
\hline
\end{tabular}

21. Percentage Distribution of the Respondents According to Their Response on Empowerment of Using Loan Money Independently.

\begin{tabular}{|l|l|l|l|l|}
\hline $\begin{array}{l}\text { Empowerment: Use of loan money } \\
\text { independently }\end{array}$ & Present & Before & \\
\cline { 3 - 6 } & Frequency & \% (Total) & Frequency & \% (Total) \\
\hline Can always & 41 & 68.3 & - & - \\
\hline
\end{tabular}


Livelihood Improvement of Poor People through Microcredit in Bangladesh

\begin{tabular}{|l|l|l|l|l|}
\hline Can sometimes & 19 & 31.7 & - & - \\
\hline Can not & - & & - & - \\
\hline Total & $\mathbf{6 0}$ & $\mathbf{1 0 0 . 0}$ & - & - \\
\hline
\end{tabular}

Reasons: (If cannot)

\begin{tabular}{|l|l|l|l|l|}
\hline \multirow{2}{*}{ Reasons } & Present & \multicolumn{2}{l|}{ Before } \\
\cline { 2 - 5 } & Frequency & $\mathbf{( \% )}$ Total & Frequency & $(\boldsymbol{\%})$ Total \\
\hline Husband does not like it & - & - & & \\
\hline Others family members do not like it & - & - & & \\
\hline I do not consider myself able/fit & - & - & & \\
\hline Surroundings condition is not favorable & - & - & & \\
\hline Total & - & - & & \\
\hline
\end{tabular}

22. Percentage Distribution of the Respondents According to Their Response on Empowerment of Working outside for Earning.

\begin{tabular}{|l|l|l|l|l|}
\hline Empowerment: working outside for & Present & \multicolumn{2}{l|}{ Before } \\
\cline { 2 - 5 } earning & Frequency & \% (Total) & Frequency & \% (Total) \\
\hline Can always & 18 & 30.0 & 1 & 1.7 \\
\hline Can sometimes & 40 & 66.7 & 16 & 26.7 \\
\hline Cannot/could not & 2 & 3.3 & 41 & 68.3 \\
\hline Not Reported & - & - & 2 & 3.3 \\
\hline Total & $\mathbf{6 0}$ & $\mathbf{1 0 0 . 0}$ & $\mathbf{6 0}$ & $\mathbf{1 0 0 . 0}$ \\
\hline
\end{tabular}

Reasons: (If cannot)

\begin{tabular}{|l|l|l|l|l|}
\hline \multirow{2}{*}{ Reasons } & Present & \multicolumn{2}{l|}{ Before } \\
\cline { 2 - 5 } & Frequency & $(\boldsymbol{\%})$ Total & Frequency & $(\boldsymbol{\%})$ Total \\
\hline Husband does not like it & 1 & 50.0 & 13 & 31.8 \\
\hline Others family members do not like it & 1 & 50.0 & 15 & 36.5 \\
\hline I do not consider myself able/fit & - & - & 6 & 14.7 \\
\hline Surroundings condition is not favorable & - & - & 7 & 17.0 \\
\hline Total & $\mathbf{2}$ & $\mathbf{1 0 0 . 0}$ & $\mathbf{4 1}$ & $\mathbf{1 0 0 . 0}$ \\
\hline
\end{tabular}

23. Percentage Distribution of the Respondents according to Their Response on Empowerment of Participating in Samity Meeting.

\begin{tabular}{|l|l|l|l|l|}
\hline \multirow{2}{*}{$\begin{array}{l}\text { Empowerment: } \\
\text { meeting }\end{array}$} & Participating in samity & Present & Before \\
\cline { 2 - 5 } & Frequency & \% (Total) & Frequency & \% (Total) \\
\hline Can always & 56 & 93.3 & 2 & 3.3 \\
\hline Can sometimes & 4 & 6.7 & 5 & 8.3 \\
\hline Cannot/could not & - & - & 49 & 81.7 \\
\hline Not Reported & - & - & 4 & 6.7 \\
\hline Total & $\mathbf{6 0}$ & $\mathbf{1 0 0 . 0}$ & $\mathbf{6 0}$ & $\mathbf{1 0 0 . 0}$ \\
\hline
\end{tabular}

Reasons: (If cannot)

\begin{tabular}{|l|l|l|l|l|}
\hline \multirow{2}{*}{ Reasons } & Present & \multicolumn{2}{l|}{ Before } \\
\cline { 2 - 5 } & Frequency & $(\boldsymbol{\%})$ Total & Frequency & $(\boldsymbol{\%})$ Total \\
\hline Husband does not like it & - & - & 17 & 34.7 \\
\hline Others family members do not like it & - & - & 10 & 20.4 \\
\hline I do not consider myself able/fit & - & - & 5 & 10.2 \\
\hline Surroundings condition is not favorable & - & - & 17 & 34.7 \\
\hline Total & - & - & $\mathbf{4 9}$ & $\mathbf{1 0 0 . 0}$ \\
\hline
\end{tabular}

24. Percentage Distribution of the Respondents According to Their Response on Empowerment of Taking Decision on Any Issue of the Family.

\begin{tabular}{|l|l|l|l|l|}
\hline Empowerment: Taking decision on any & Present & \multicolumn{2}{l|}{ Before } \\
\cline { 2 - 5 } issue of the family & Frequency & \% (Total) & Frequency & \% (Total) \\
\hline Can always & 41 & 68.3 & 1 & 1.7 \\
\hline Can sometimes & 19 & 31.7 & 17 & 28.3 \\
\hline Cannot/could not & - & - & 40 & 66.7 \\
\hline Not Reported & - & - & 2 & 3.3 \\
\hline Total & $\mathbf{6 0}$ & $\mathbf{1 0 0 . 0}$ & $\mathbf{6 0}$ & $\mathbf{1 0 0 . 0}$ \\
\hline
\end{tabular}


Reasons: (If cannot)

\begin{tabular}{|l|l|l|l|l|}
\hline \multirow{2}{*}{ Reasons } & Present & \multicolumn{2}{l|}{ Before } \\
\cline { 2 - 5 } & Frequency & $(\boldsymbol{\%})$ Total & Frequency & $(\boldsymbol{\%})$ Total \\
\hline Husband does not like it & - & - & 18 & 45.0 \\
\hline Others family members do not like it & - & - & 12 & 30.0 \\
\hline I do not consider myself able/fit & - & - & 10 & 25.0 \\
\hline Surroundings condition is not favorable & - & - & - & \\
\hline Total & - & - & $\mathbf{4 0}$ & $\mathbf{1 0 0 . 0}$ \\
\hline
\end{tabular}

25. Percentage Distribution of the Respondents according to Their Response on Empowerment of Visiting Relative's House.

\begin{tabular}{|l|l|l|l|l|}
\hline \multirow{2}{*}{ Empowerment: Visiting relative's house } & Present & Before & \multicolumn{2}{|l|}{} \\
\cline { 2 - 5 } & Frequency & \% (Total) & Frequency & (Total) \\
\hline Can always & 32 & 53.3 & - & - \\
\hline Can sometimes & 28 & 46.7 & 33 & 55.0 \\
\hline Cannot/could not & - & - & 27 & 45.0 \\
\hline Not Reported & - & - & - & - \\
\hline Total & $\mathbf{6 0}$ & $\mathbf{1 0 0 . 0}$ & $\mathbf{6 0}$ & $\mathbf{1 0 0 . 0}$ \\
\hline
\end{tabular}

Reasons: (If cannot)

\begin{tabular}{|l|l|l|l|l|}
\hline \multirow{2}{*}{ Reasons } & Present & Before & \multicolumn{1}{l|}{} \\
\cline { 2 - 5 } & Frequency & $(\boldsymbol{\%})$ Total & Frequency & $(\boldsymbol{\%})$ Total \\
\hline Husband does not like it & - & - & 15 & 55.6 \\
\hline Others family members do not like it & - & - & 10 & 37.0 \\
\hline I do not consider myself able/fit & - & - & - & - \\
\hline Surroundings condition is not favorable & - & - & 2 & 7.4 \\
\hline Total & - & - & $\mathbf{2 7}$ & $\mathbf{1 0 0 . 0}$ \\
\hline
\end{tabular}

26. Percentage Distribution of the Respondents According to Their Response on Empowerment of Spending Own Earning Money.

\begin{tabular}{|l|l|l|l|l|}
\hline \multirow{2}{*}{$\begin{array}{l}\text { Empowerment: Spending of own } \\
\text { earning money }\end{array}$} & Present & Before & \multicolumn{1}{l|}{} \\
\cline { 2 - 6 } & Frequency & \% (Total) & Frequency & \% (Total) \\
\hline Can always & 28 & 46.7 & - & - \\
\hline Can sometimes & 32 & 53.3 & 14 & 23.3 \\
\hline Cannot/could not & - & - & 46 & 76.7 \\
\hline Not Reported & - & - & - & - \\
\hline Total & $\mathbf{6 0}$ & $\mathbf{1 0 0 . 0}$ & $\mathbf{6 0}$ & $\mathbf{1 0 0 . 0}$ \\
\hline
\end{tabular}

Reasons: (If cannot)

\begin{tabular}{|l|l|l|l|l|}
\hline \multirow{2}{*}{ Reasons } & Present & Before & \multicolumn{2}{l|}{} \\
\cline { 2 - 5 } & Frequency & $(\boldsymbol{\%})$ Total & Frequency & $(\boldsymbol{\%})$ Total \\
\hline Husband does not like it & - & - & 24 & 52.1 \\
\hline Others family members do not like it & - & - & 10 & 21.8 \\
\hline I do not consider myself able/fit & - & - & 2 & 4.3 \\
\hline Surroundings condition is not favorable & - & - & 10 & 21.8 \\
\hline Total & - & - & $\mathbf{4 6}$ & $\mathbf{1 0 0}$ \\
\hline
\end{tabular}

27. Percentage Distribution of the Respondents According to Their Response on Empowerment of Participating Village Arbitration System.

\begin{tabular}{|l|l|l|l|l|}
\hline \multirow{2}{*}{$\begin{array}{l}\text { Empowerment: Participating in Village } \\
\text { arbitration system }\end{array}$} & Present & Before & (Total) \\
\cline { 2 - 5 } & Frequency & \% (Total) & Frequency & \% (Total \\
\hline Can always & 6 & 10.0 & - & - \\
\hline Can sometimes & 58 & 90.0 & 2 & 3.3 \\
\hline Cannot/could not & - & - & 58 & 96.7 \\
\hline Not Reported & - & - & & - \\
\hline Total & $\mathbf{6 0}$ & $\mathbf{1 0 0 . 0}$ & $\mathbf{6 0}$ & $\mathbf{1 0 0 . 0}$ \\
\hline
\end{tabular}

Reasons: (If cannot)

\begin{tabular}{|l|l|l|l|l|}
\hline \multirow{2}{*}{ Reasons } & Present & Before & \\
\cline { 2 - 5 } & Frequency & $\boldsymbol{( \% )}$ Total & Frequency & $(\boldsymbol{\%})$ Total \\
\hline Husband does not like it & - & - & 31 & 53.4 \\
\hline
\end{tabular}


Livelihood Improvement of Poor People through Microcredit in Bangladesh

\begin{tabular}{|l|l|l|l|l|}
\hline Others family members do not like it & - & - & 12 & 20.7 \\
\hline I do not consider myself able/fit & - & - & 5 & 8.7 \\
\hline Surroundings condition is not favorable & - & - & 10 & 17.2 \\
\hline Total & - & - & $\mathbf{5 8}$ & $\mathbf{1 0 0 . 0}$ \\
\hline
\end{tabular}

28. Percentage Distribution of the Respondents According to Their Response on Empowerment of Husband Counts Them in Any Issue.

\begin{tabular}{|l|l|l|l|l|}
\hline \multirow{2}{*}{$\begin{array}{l}\text { Empowerment: Husband count them in } \\
\text { any issue }\end{array}$} & Present & Before & \multicolumn{2}{l|}{} \\
\cline { 2 - 5 } & Frequency & \% (Total) & Frequency & \% (Total) \\
\hline Can always & 41 & 68.3 & - & - \\
\hline Can sometimes & 19 & 31.7 & 23 & 38.3 \\
\hline Cannot/could not & - & - & 37 & 61.7 \\
\hline Not Reported & - & - & - & - \\
\hline Total & $\mathbf{6 0}$ & $\mathbf{1 0 0 . 0}$ & $\mathbf{6 0}$ & $\mathbf{1 0 0 . 0}$ \\
\hline
\end{tabular}

Reasons: (If cannot)

\begin{tabular}{|l|l|l|l|l|}
\hline \multirow{2}{*}{ Reasons } & Present & Before & \\
\cline { 2 - 5 } & Frequency & $\mathbf{( \% )}$ Total & Frequency & $(\boldsymbol{\%})$ Total \\
\hline Husband does not like it & - & - & 20 & 54.0 \\
\hline Others family members do not like it & - & - & 7 & 19.0 \\
\hline I do not consider myself able/fit & - & - & 5 & 13.5 \\
\hline Surroundings condition is not favorable & - & - & 5 & 13.5 \\
\hline Total & - & - & $\mathbf{5 8}$ & $\mathbf{1 0 0 . 0}$ \\
\hline
\end{tabular}

29. Percentage Distribution of the Respondents According to Their Response on Having Sanitary Latrine in the Household

\begin{tabular}{|l|l|l|l|l|}
\hline \multirow{2}{*}{ Having sanitary latrine } & Present & Before \\
\cline { 2 - 5 } & Frequency & \% (Total) & Frequency & \% (Total) \\
\hline Yes & 59 & 98.3 & - & - \\
\hline No & 1 & 1.7 & 60 & 100.0 \\
\hline Total & $\mathbf{6 0}$ & $\mathbf{1 0 0 . 0}$ & $\mathbf{6 0}$ & $\mathbf{1 0 0 . 0}$ \\
\hline
\end{tabular}

30. Percentage Distribution of the Respondents According to Their Response on Increasing Social Acceptance.

\begin{tabular}{|l|l|l|l|l|}
\hline \multirow{2}{*}{ Increased social acceptance } & Present & Before & \\
\cline { 2 - 5 } & Frequency & \% (Total) & Frequency & \% (Total) \\
\hline Yes & 59 & 98.3 & - & - \\
\hline No & 1 & 1.7 & - & - \\
\hline Total & $\mathbf{6 0}$ & $\mathbf{1 0 0 . 0}$ & $\mathbf{6 0}$ & $\mathbf{1 0 0 . 0}$ \\
\hline
\end{tabular}

AUTHOR'S BIOGRAPHY

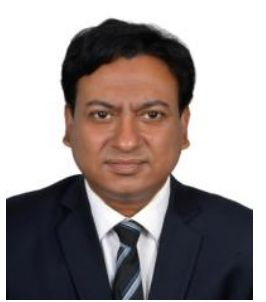

Dr. A.H.M Mahbubur Rahman, was born on $1^{\text {st }}$ February 1974 in Jamalpur District, Bangladesh. He obtained his PhD degree from Jahangir Nagar University, Master and Bachelor degree in Social Work from Rajshahi University, Bangladesh. $\mathrm{He}$ has extensive specialization in Social Work theory, practices and research methods. He teaches a number of courses of Social Work to undergraduate and graduate level students. He also supervises field work activities conducted by the graduate level social work students. He has also published some books and articles. He regularly writes columns and essays on contemporary issues in the daily newspaper published from Bangladesh. He is involved in different social and cultural organizations. Currently he is an Assistant Professor and Chairman in the Department of Social Work, Bangamata Sheikh Fojilatunnesa Mujib Science and Technology University, Jamalpur.

Citation: A.H.M Mahbubur Rahman. "Livelihood Improvement of Poor People through Microcredit in Bangladesh" International Journal of Humanities Social Sciences and Education (IJHSSE), vol 8, no. 3, 2021, pp. 109-124. doi: https://doi.org/10.20431/2349-0381.0803011.

Copyright: (C) 2021 Authors. This is an open-access article distributed under the terms of the Creative Commons Attribution License, which permits unrestricted use, distribution, and reproduction in any medium, provided the original author and source are credited. 